\title{
Methylenetetrahydrofolate Reductase Polymorphism in the Etiology of Down Syndrome
}

\author{
BERNADETTE CHADEFAUX-VEKEMANS, MARIE COUDÉ, FRANÇOISE MULLER, \\ JEAN FRANÇOIS OURY, ALLEL CHABLI, JEAN PHILIPPE JAÏS, AND PIERRE KAMOUN
}

Laboratoire de Biochimie, UMR CNRS 8602, Hôpital Necker-Enfants Malades, 75743 Paris Cedex 15, France [B.C.-V., P.K., A.C.]; Laboratoire de Biologie Moléculaire, Centre Hospitalier, 72000 Le Mans, France [M.C.]; Service Obstétrique, Hôpital Robert Debré, 75019 Paris, France [J.F.O.]; Laboratoire de Biochimie, Hôpital Ambroise Paré, 92100 Boulogne, France [F.M.]; Biomathematique, Hôpital Necker-Enfants Malades, 75743 Paris Cedex 15, France [J.P.J] \begin{abstract}
ABST
A methylenetetrahydrofolate reductase polymorphism $(677 \mathrm{C} / \mathrm{T}$
mutation) was recently implicated in the etiology of Down syndrome. We studied a cohort of 85 women carrying fetuses with Down syndrome and found no difference in the frequencies of the three groups of subjects $(\mathrm{C} / \mathrm{C}, \mathrm{C} / \mathrm{T}, \mathrm{T} / \mathrm{T})$ between Down syndrome mothers and controls. (Pediatr Res 51: 766-767, 2002)
\end{abstract}

DS, Down syndrome

Abbreviations

MTHFR, methylenetetrahydrofolate reductase
In most cases of DS, the extra chromosome is present as a result of the failure of normal chromosome segregation during meiosis. The nondisjunction event is maternal in $95 \%$ of cases, occurring primarily during meiosis 1 in the maturing ovocyte before conception. Despite the high prevalence of DS, the mechanisms underlying meiotic nondisjunction are not yet understood. Abnormal folate metabolism and mutation of the MTHFR (EC 1.5.1.20) gene have recently been described as a possible cause of DS (1). The aim of this study was to check the results obtained by James et al. (1) by studying a cohort of women carrying DS fetuses.

\section{MATERIALS AND METHODS}

For the control group, 107 volunteers were recruited (37 men, 70 women; median age $40 \mathrm{y}$, mean age $43.2 \pm 17.7 \mathrm{y}$, range $17-90 \mathrm{y})$. All were shown to be free from clinical symptoms of vascular disease.

Amniocentesis was performed between 16 and $24 \mathrm{wk}$ in pregnant women aged $>35$ y or if echographic signs of DS or abnormal serum hormonal markers were suggestive of this diagnosis. Selection criteria were induced abortion of a fetus

Received June 14, 2000; accepted January 16, 2001.

Correspondence: Pierre Kamoun, Laboratoire de Biochimie Médicale B, UMR-CNRS 8602, Hôpital Necker-Enfants Malades, 75743 Paris Cedex 15, France; e-mail: pierre.kamoun@nck.ap-hop-paris.fr

Supported by the Association Française pour la Recherche sur la Trisomie 21 and the Institut de Recherches Internationales Servier.

DOI: 10.1023/01.PDR.0000017484.64723.43 with karyotypically confirmed full trisomy 21 without translocation. No DS mothers with live births were studied. The 85 DS mothers were aged $34.9 \pm 5.0$ y (range $20-47$ y). DNA polymorphisms of chromosome 21 were used to determine the parental origin of the extra chromosome 21 and the stage at which the meiotic error occurred (2). Genomic DNA was extracted from lymphocytes from DS mothers by standard procedures. For genotype analysis, the MTHFR gene was amplified by PCR after restriction enzyme digestion with HinfI using the primers and conditions described by Goyette et al. (3). Total plasma homocysteine was determined by immunoassay (Abbott Laboratories, North Chicago, IL, U.S.A.) using serum obtained from DS mothers and 39 pregnant women with normal fetuses to check serum hormonal markers of trisomy 21. In all cases, informed consent was obtained from the pregnant women and volunteers of control group for biochemical or molecular biologic investigations. This study was approved by Institutional Review Board of Hôpital Necker.

\section{RESULTS}

The frequencies of the $\mathrm{C} / \mathrm{C}, \mathrm{C} / \mathrm{T}$, and $\mathrm{T} / \mathrm{T}$ genotypes among the DS mothers with maternal nondisjunction did not differ from those of the control subjects (Table 1). If DS mothers were assigned to two groups according to age ( $>$ or $<40$ y) no difference was observed $\left(\chi^{2}=0.35\right)$ between the two groups in MTHFR genotypes (Table 1). The stage of meiotic error was also used to separate DS mothers in two groups. Again, no difference $\left(\chi^{2}=2.58\right)$ was observed between the two groups 
Table 1. MTHFR polymorphism in DS and controls

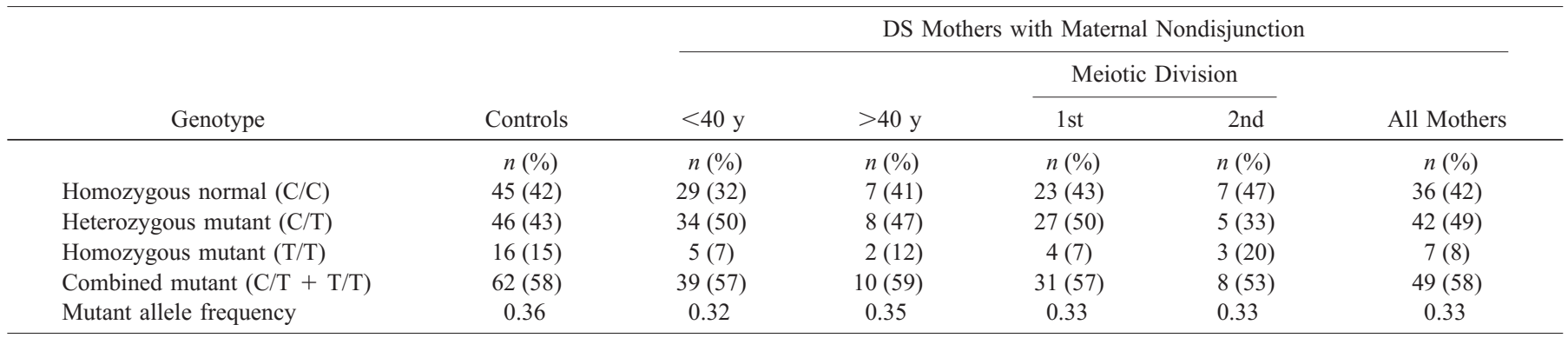

(Table 1). Total plasma homocysteine concentrations in the pregnant women are shown in Table 2. No differences ( $t$ test) were observed between the various groups of subjects (homozygous, heterozygous, or normal subjects for the $677 \mathrm{C} / \mathrm{T}$ mutation) either in the control or DS mother groups.

\section{DISCUSSION}

MTHFR acts at a critical metabolic juncture in the regulation of cellular methylation reactions, catalyzing the conversion of 5,10-methylenetetrahydrofolate to 5-methyltetrahydrofolate, the methyl donor for the remethylation of homocysteine to give methionine. A frequent mutation, described as the thermolabile mutation (677 C/T MTHFR mutation), may modify enzymatic activity. The specific activity of MTHFR is low in the heterozygous $\mathrm{C} / \mathrm{T}$ genotype and in the homozygous $\mathrm{T} / \mathrm{T}$ genotype (35\% and $70 \%$ of the $\mathrm{C} / \mathrm{C}$ genotype, respectively). James et al. (1) described a significantly higher frequency of this mutation in 57 mothers of children with DS than in 50 control women. They recently extended their study (4) to 157 DS mothers and 140 control women and obtained similar results. Our results differ from those recently described (4). Some differences were observed between the groups of DS mothers studied. We took into account all DS cases, whereas James et al. $(1,4)$ studied only mothers of liveborn DS children. The percentage of the various genotypes in the controls was similar in the two studies. It is well known that the effect of the T/T genotype on plasma homocysteine concentration is related to folate intake (5), the T/T genotype only inducing hyperhomocystinemia if associated with a low intake of folate. Therefore, we determined total fasting serum homocysteine in DS mothers according to genotype. No hyperhomocystinemia was detected in the three groups of DS mothers. James et al. (1) found hyperhomocystinemia in the T/T DS mothers, but the homocysteine determinations were performed many months after the delivery and it is not clear whether hyperhomocystinemia occurred during pregnancy. Our determinations of total plasma homocysteine concentration were performed closer to conception
Table 2. Total fasting plasma homocysteine in DS mothers and control subjects

\begin{tabular}{lccc}
\hline \multicolumn{1}{c}{ Genotype } & Controls & DS Mothers & $\begin{array}{c}\text { Pregnant } \\
\text { Women with } \\
\text { Normal Fetuses }\end{array}$ \\
\hline Homozygous normal (C/C) & $8.0 \pm 2.2(27)$ & $8.6 \pm 2.4(21)$ & - \\
Heterozygous mutant (C/T) & $8.7 \pm 3.1(32)$ & $9.2 \pm 1.8(19)$ & - \\
Homozygous mutant (T/T) & $9.0 \pm 4.4(10)$ & $8.6 \pm 1.4(5)$ & - \\
Not determined & - & - & $8.4 \pm 2.9(39)$ \\
\hline
\end{tabular}

Mean $\pm \mathrm{SD} \mu \mathrm{mol} / \mathrm{L}$; number of subjects in parentheses.

(between 16 and 24 wk of pregnancy). Some differences between traditional French and American diets may account for the lack of hyperhomocystinemia in our subjects, even in the T/T genotype subjects. The search for the etiology of chromosome 21 nondisjunction is of great importance. It is therefore essential to discriminate clearly between the possible etiologic factors. Hyperhomocystinemia may be one of these factors, and it is probably of value to determine homocysteine in the plasma of pregnant women early during the pregnancy, along with hormonal markers, and to correlate plasma homocysteine concentration with the delivery of DS fetuses.

\section{REFERENCES}

1. James SJ, Pogribna M, Pogribny IP, Melnyk S, Hine RJ, Gibson JB, Yi P, Tafoya DL, Swenson DH, Wilson VL, Gaylor DW 1999 Abnormal folate metabolism and mutation in the methylenetetrahydrofolate reductase gene may be maternal risk factors for Down syndrome. Am J Clin Nutr 70:495-501

2. Antonarakis SE, Petersen MB, McInnis MG, Adelsberger PA, Schinzel AA, Binker F, Pangalos C, Raoul O, Slaugenhaupt SA, Hafez M, Cohen MM, Roulson D, Schwartz S, Mikkelsen M, Tranebjaerg L, Greenberg F, Hoar DI, Rudd NL, Warren AC, Metaxotou C, Bartsocas C, Chakravati A 1992 The meiotic stage of non disjunction in trisomy 21: determination by using DNA polymorphisms. Am J Hum Genet 50:544550

3. Goyette P, Summer JS, Milos R, Duncan AM, Rosenblatt DS, Mattews RG, Rozen R 1994 Human methylenetetrahydrofolate reductase: isolation of cDNA, mapping and mutation identification. Nat Genet 7:195-200

4. Hobbs CA, Sherman SL, Yi P, Hopkins SE, Torfs CP, Hine RJ, Pogribna M, Rozen, James SJ 2000 Polymorphisms in genes involved in folate metabolism as maternal risk factors for Down syndrome. Am J Hum Genet 67:623-630

5. Jacques PF, Boston AG, Williams RR, Ellison RC, Eckfeldt JH, Rosengerg IH, Selhub J, Rosen R 1996 Relation between folate, a common mutation in methylenetetrahydrofolate reductase, and plasma homocysteine concentrations. Circulation 93:7-9 